Article

\title{
Experimental and Potential Analysis of a Single-Valve Expander for Waste Heat Recovery of a Gasoline Engine
}

\author{
Wenzhi Gao ${ }^{1, *}$, Wangbo $\mathrm{He}^{1}$, Lifeng Wei ${ }^{1}$, Guanghua $\mathrm{Li}^{2}$ and Ziqi Liu ${ }^{1}$ \\ 1 State Key Laboratory of Engines, Tianjin University, Tianjin 300072, China; hewangbo@tju.edu.cn (W.H.); \\ weilifeng@tju.edu.cn (L.W.); liuziqi@borgward.com (Z.L.) \\ 2 School of Automotive Engineering, Changshu Institute of Technology, Changshu 215500, China; \\ lgh@tju.edu.cn \\ * Correspondence: gaowenzhi@tju.edu.cn; Tel.: +86-22-2740-6781; Fax: +86-22-2740-4244 \\ Academic Editors: Fredrik Haglind and Saiful Bari \\ Received: 8 September 2016; Accepted: 26 November 2016; Published: 30 November 2016
}

\begin{abstract}
In this paper, a Rankine cycle test system is established to recover exhaust energy from a 2.0 L gasoline engine. Experiments on the system's performance are carried out under various working conditions. The experimental results indicate that the recovery power of the expander is strongly related to the load and speed of the gasoline engine. It is found that when the output power of the gasoline engine is $39.8-76.6 \mathrm{~kW}$, the net power of the expander is $1.8-2.97 \mathrm{~kW}$, which is equivalent to $3.9 \%-4.9 \%$ of the engine power. The performance simulation shows that the mass flow rate, power output, and isentropic efficiency of the piston expander are directly determined by the intake valve timing. Selecting a suitable intake valve timing can optimize the performance of the expander. The simulation results show that a $1 \mathrm{~kW}$ increment in power can be obtained only by selecting an optimum intake open timing. The experimental results further verify that the single-valve piston expander, because of its small dimensions, simple structure, and high speed, is appropriate, and has great potential for energy recovery of gasoline engine exhaust and has good prospects for engineering applications.
\end{abstract}

Keywords: waste heat recovery; gasoline engine; Rankine cycle; piston expander; intake valve timing

\section{Introduction}

With the increasing use of technology, the demand for energy is surging at an unprecedented rate [1]. This offers significant opportunities to save energy and protect the environment [2]. Internal combustion engines (ICEs) are the major source of mobile power in the world, and will likely continue to be for some decades [3]. However, on average, two-thirds of the energy obtained from the fuel used is still wasted through exhaust gases and coolants and lost in the form of heat $[4,5]$. Recovering this wasted energy, particularly energy wasted through exhaust is, therefore, of great significance [6,7]. There are several technologies for the recovery of wasted energy from an ICE [8]. One solution is to integrate a waste heat recovery system based on a Rankine cycle [9-12] into the engine, which this paper addresses.

In the 1970s, the idea of recovering waste heat from automotive ICEs using the Rankine cycle was conceived [13]. However, the idea was discarded owing to its mechanical complexity and the loss in power-to-weight ratios that would inevitably result. Today, many researchers recognize that recovering waste heat from engine exhaust has the potential to decrease fuel consumption without increasing emissions, and recent advances in technology have made these systems viable and cost effective [14]. Many researchers have concluded that the Rankine cycle system is highly effective in 
recovering waste heat from ICEs [15-17]; thus, research in this area has become significant worldwide. Hajabdollahi et al. [18] built a model of a Rankine cycle system for diesel engine waste heat recovery and analysed the thermal efficiency and total annual cost of the system. Gunnar et al. [19] discussed experimental results and practical challenges while utilizing a waste heat recovery system in the exhaust gas recirculation system of a truck engine. Zhang et al. [20] designed an integrated Rankine cycle system and used a screw expander to recover waste heat from a diesel engine. When the diesel engine operated at $250 \mathrm{~kW}$, the output power of the single screw expander was $10.38 \mathrm{~kW}$.

In the waste heat recovery system of a Rankine cycle system, one of the key parts is the expander, which has an important influence on system performance. There are many types of expanders for a Rankine cycle system [21]. Vane expanders are likely choices because they can provide high expansion ratios and acceptable performance over a wide range of operations with a simple design and low cost. In addition, it is relatively easy to scale them down over a wide range of 1-10 $\mathrm{kW}$. The rotary vane expander is a good option when the required power output is lower than $2 \mathrm{~kW}$ [22]. Kolasinski et al. conducted experimental and numerical analyses on a rotary vane expander used in a micro-organic Rankine cycle (micro-ORC) system. The experimental results showed that the rotary vane expander could be adopted in micro-ORC systems if its sealing and bearing issues were solved [23].

Gnutek et al. analysed the use of a vane rotary expander with a low-boiling working fluid for small-capacity ORC systems. The experimental results revealed that the system could generate approximately $1.2 \mathrm{~kW}$, which was equivalent to approximately $10 \%$ of the net conversion efficiency. Moreover, the experiment proved that the ORC system power and efficiency are dependent on the working fluid mass flow [24].

The turbo expander, which is widely used in industrial power generation, is not suitable for cases with a small gas flow rate because its miniaturization results in reduced efficiency and increased cost. Large-scale systems above approximately $50 \mathrm{~kW}$ employ turbo expanders because of their relatively high expansion efficiency at higher power ratings [25]. When the power is below $50 \mathrm{~kW}$, the performance of turbo expanders begins to deteriorate until unacceptable efficiencies are reached at $10 \mathrm{~kW}$ [26]. Moreover, their units are very expensive and their reliability has yet to be proven [27,28].

However, a piston expander has higher thermal efficiency under low steam-flow-rate conditions and a good power output/size ratio. This type of expander is generally built or renovated based on existing commercial IC engines [29-34]. Endo et al. [35] studied a piston expander used in a Rankine cycle system to recover waste heat from hybrid electric vehicle exhaust. In this study, the use of a recovery device increased the overall recovery system efficiency from $28.9 \%$ to $32.7 \%$. Yulia et al. [36] proposed a steady-state semi-empirical model to study the performance of a piston expander. The results indicated that the piston expander has relatively high entropy and mechanical efficiency and is suitable for engine waste heat recovery. Chiong et al. [37] used a nozzle piston expander instead of a conventional expander to recover exhaust energy. Simulation results showed that the nozzle piston expander could increase output power from a minimum of $0.73 \mathrm{~kW}$ to a maximum of $4.75 \mathrm{~kW}$, and has the potential to improve engine system level efficiency.

The single-valve expander is a type of piston expander. Due to its reliability, simple structure, and high compression ratio, this type of piston expander has been widely used in compressed-air energy storage systems and small cooling equipment. However, it has not yet been used in engine waste heat recovery systems. Therefore, in this study, a single-valve piston expander is applied to a waste heat recovery system and is tested to assess system performance using several indices. In addition, an optimization method is proposed.

\section{Experimental System for Waste Heat Recovery}

In the system being studied, a Rankine cycle system employs a single-valve piston expander to recover exhaust heat from a 2.0 L Naturally aspirated (NA) gasoline engine. Experiments are conducted to evaluate the performance of the expander. 


\subsection{Experimental Principle and Bench Description}

The test bench for the waste heat recovery system is shown in Figures 1 and 2 . The system consists of a dynamometer, gasoline engine, Rankine cycle system, control system, and data acquisition system. The dimensions of the Rankine cycle system are $0.95 \times 0.57 \times 0.50 \mathrm{~m}^{3}$. The parameters for the main equipment of the test system are listed in Table 1.

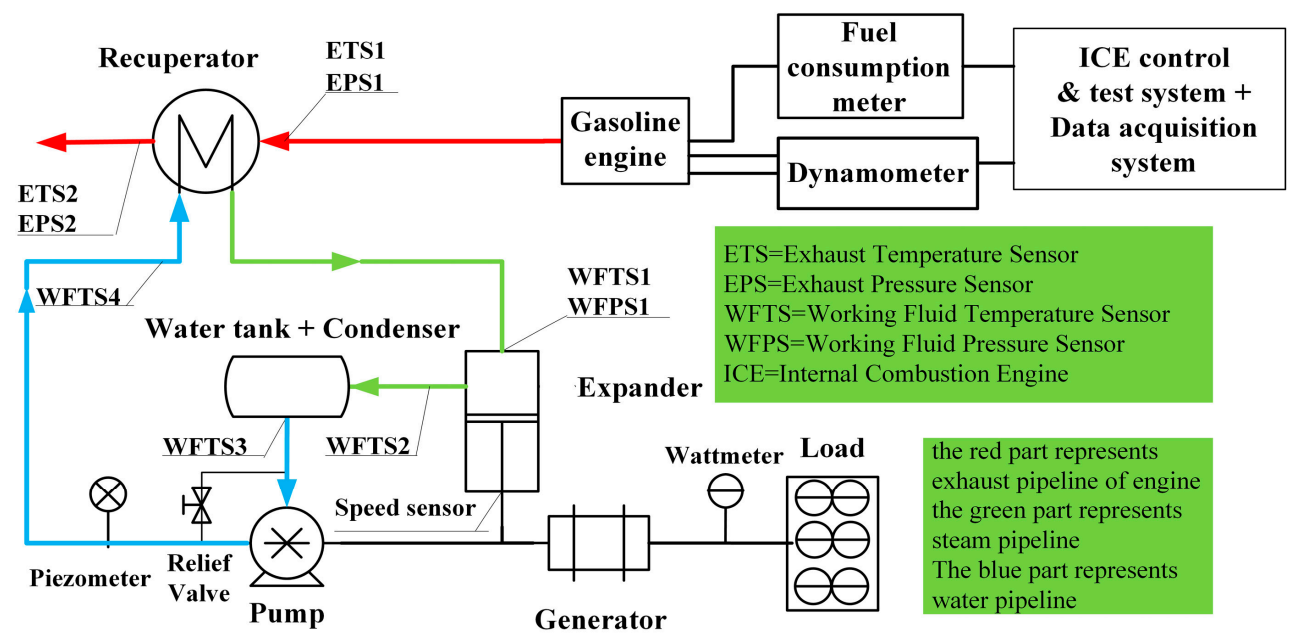

Figure 1. Schematic of the test bench.

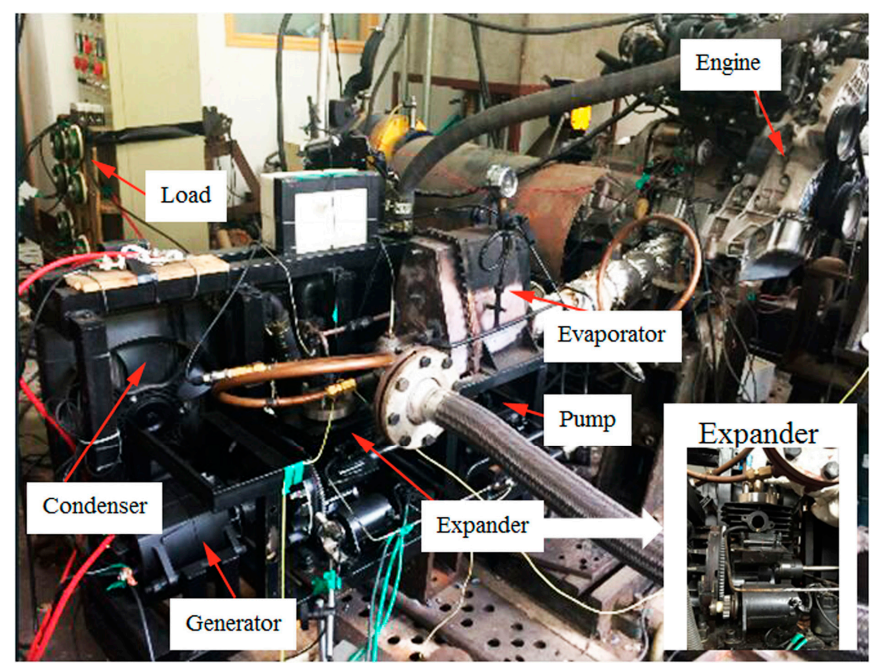

Figure 2. Test bench of the waste heat recovery system.

In a waste heat recovery system, water is chosen as the working fluid. In a Rankine cycle system, which recovers only exhaust heat, water is the most efficient refrigerant. It is also the best working medium when the exhaust temperature of a gasoline engine ranges between 500 and $800{ }^{\circ} \mathrm{C}[38,39]$. Water is pumped to the recuperator by a high-pressure pump and then heated by exhaust gas. The water converts to steam at a high temperature and pressure. One side of the expander output shaft connects to the generator to produce electrical power; the other side connects to the working fluid pump to drive it and produce pressure. The exhaust steam then condenses in the condenser, and the water flows into the working fluid tank. The recuperator is located behind and close to a three-way catalyst. 
Table 1. Parameters for the main instruments of test system.

\begin{tabular}{ccc}
\hline Instruments & Type & Parameter \\
\hline Gasoline engine & $2.0 \mathrm{NA}$ & Table 2 \\
Expander & Customization & Table 3 \\
Recuperator & Customization & Multilayer spiral tubes Heat transfer area 1 $\mathrm{m}^{2}$ \\
Generator & 8SC3238VC & Regulated DC 28 V/150 A \\
\hline
\end{tabular}

Table 2. Parameters of the 2.0 NA gasoline engine.

\begin{tabular}{ccc}
\hline Parameter & Unit & Value \\
\hline Cylinder number & - & 4 \\
Bore & $\mathrm{mm}$ & 83 \\
Stroke & $\mathrm{mm}$ & 91 \\
Compression ratio & - & 10.3 \\
Rated power & $\mathrm{kW}$ & 110 \\
Rated speed & $\mathrm{r} / \mathrm{min}$ & 6300 \\
Maximum torque & $\mathrm{Nm}$ & 183 \\
Speed at maximum torque & $\mathrm{r} / \mathrm{min}$ & 4500 \\
\hline
\end{tabular}

Table 3. Parameters of the expander.

\begin{tabular}{ccc}
\hline Parameter & Unit & Value \\
\hline Cylinder number & - & 1 \\
Bore & $\mathrm{mm}$ & 50 \\
Stroke & $\mathrm{mm}$ & 50 \\
Connecting rod length & $\mathrm{mm}$ & 100 \\
Speed & $\mathrm{r} / \mathrm{min}$ & $1000-4000$ \\
\hline
\end{tabular}

\subsection{Test and Data Acquisition System}

The test and data acquisition system includes cylinder pressure sensors, temperature sensors, speed sensors, back-pressure sensors, and an output power meter. The sensor placement is shown in Figure 1. An NIPCI-6132 (National Instruments, Austin, TX, USA) card is used in the data acquisition system. $K$-type thermocouple temperature sensors are used to measure the temperature of the exhaust and working fluid. A 6056A pressure sensor is used to measure the expander cylinder pressure, and its sampling frequency is 10,000 Hz. The back-pressures at the recuperator and outlet of the exhaust are measured by back-pressure sensors. The output power meter measures the output power of the generator. Since the flow rate of the working fluid is mainly related to the pump speed, the mass flow rate of the working fluid is measured on a pump test bench.

\section{Experimental Results and Analysis}

In a waste heat recovery system, the output power of the expander is closely related to the running state of the engine. Variations in engine speed and load will vary the heat of the exhaust, resulting in steam pressure and temperature variations in the expander, thereby affecting the expander speed and output power. In this experiment, four conditions (listed in Table 4) of the gasoline engine are chosen to evaluate the waste heat recovery performance. Figure 3 shows a T-S diagram of the Rankine cycle for case 1 . 
Table 4. Test results of the Rankine recovery system.

\begin{tabular}{|c|c|c|c|c|c|c|}
\hline $\begin{array}{l}\text { Rankine Cycle } \\
\text { System }\end{array}$ & Parameter & Unit & Case 1 & Case 2 & Case 3 & Case 4 \\
\hline \multirow{6}{*}{$\begin{array}{c}2.0 \mathrm{NA} \\
\text { Gasoline engine }\end{array}$} & Speed & $\mathrm{r} / \mathrm{min}$ & 4000 & 4000 & 4000 & 5500 \\
\hline & Load & $\mathrm{Nm}$ & 94.5 & 108.6 & 133.7 & 133 \\
\hline & Power & $\mathrm{kW}$ & 39.6 & 45.5 & 56.0 & 76.6 \\
\hline & Exhaust temperature at inlet of recuperator & ${ }^{\circ} \mathrm{C}$ & 721 & 740 & 765 & 805 \\
\hline & Exhaust temperature at outlet of recuperator & ${ }^{\circ} \mathrm{C}$ & 411 & 398 & 390 & 445 \\
\hline & Exhaust mass flow & $\mathrm{kg} / \mathrm{s}$ & 0.052 & 0.058 & 0.067 & 0.093 \\
\hline \multirow{4}{*}{ Expander } & Steam pressure in expander cylinder & $\mathrm{MPa}$ & 3.87 & 4.23 & 5.24 & 6.69 \\
\hline & Speed & $\mathrm{r} / \mathrm{min}$ & 1352 & 1426 & 1640 & 1978 \\
\hline & Working fluid mass flow & $\mathrm{kg} / \mathrm{s}$ & 0.0053 & 0.0055 & 0.0064 & 0.0078 \\
\hline & Electrical power & $\mathrm{kW}$ & 0.515 & 0.784 & 1.393 & 2.152 \\
\hline
\end{tabular}

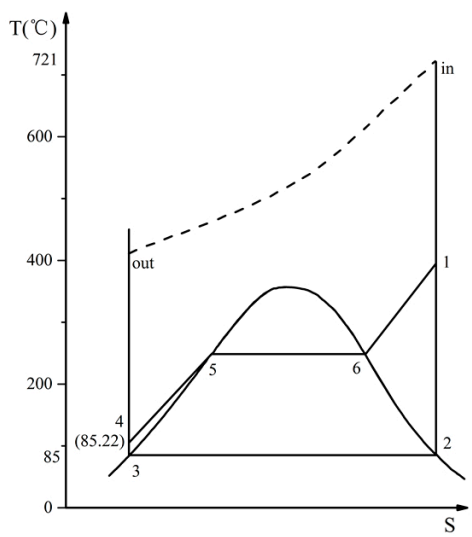

Figure 3. Rankine cycle T-S diagram for Case 1.

\subsection{Recuperator Influence on the Gasoline Engine}

Variations in the operating state of the engine will affect the output power of the waste heat recovery system, and the recuperator in the exhaust tube has an impact on the back pressure of the exhaust gas. If the exhaust gas back pressure is too high, it will decrease the power of the engine; thus, both the back-pressure and exhaust temperature are measured. The measurement results are shown in Figure 3.

As can be seen in Figure 4, the drops in exhaust temperature between the recuperator inlet (ET1) and outlet (ET2) are remarkable, reaching $300-380{ }^{\circ} \mathrm{C}$. The recuperator in the exhaust tube increased the back-pressure by a maximum of $9.4 \mathrm{kPa}$ for all four conditions. In addition, test results for fuel consumption are listed in Table 5 . The fuel consumption only increased by $0.20 \%$ when the recuperator was present in the exhaust tube.

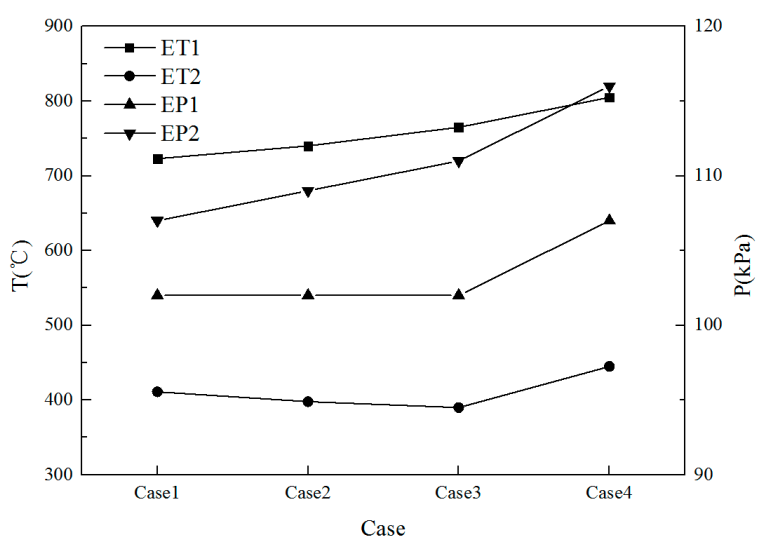

Figure 4. Exhaust pressure and temperature at the recuperator inlet and outlet. 
Table 5. Comparison between fuel consumption without and with the recuperator.

\begin{tabular}{cccc}
\hline Case & $\begin{array}{c}\text { Fuel Consumption without } \\
\text { Recuperator } \mathbf{( k g} / \mathbf{h})\end{array}$ & $\begin{array}{c}\text { Fuel Consumption with } \\
\text { Recuperator } \mathbf{( k g} / \mathbf{h})\end{array}$ & $\begin{array}{c}\text { Fuel Consumption } \\
\text { Increasing Rate }\end{array}$ \\
\hline 1 & 13.12 & 13.14 & $0.15 \%$ \\
2 & 15.33 & 15.36 & $0.20 \%$ \\
3 & 19.59 & 19.63 & $0.20 \%$ \\
4 & 27.96 & 28 & $0.14 \%$ \\
\hline
\end{tabular}

\subsection{Performance of Expander and Recovery System}

The pressure sensors installed in the expander cylinder head can measure the pressure variation with a crank angle and obtain an indicator diagram, as shown in Figure 5. This diagram indicates how the expander cylinder pressure changes with the crank angle and volume when the engine is operating as per Case $4(76.6 \mathrm{~kW}, 5500 \mathrm{r} / \mathrm{min})$.
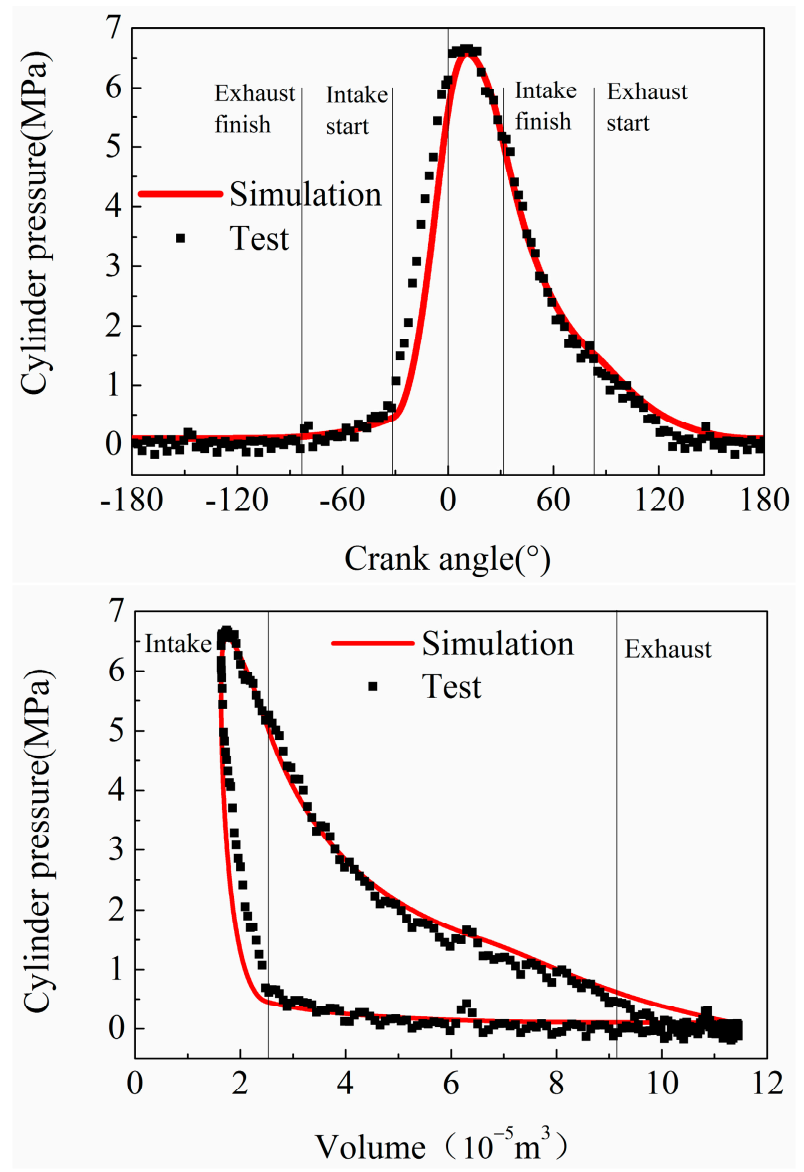

Figure 5. Indicator diagram of the expander for Case 4.

Based on the indicator diagram, the powers of the four test cases can be calculated. They are $2.23,2.63,3.44$, and $5.06 \mathrm{~kW}$, respectively. As generator power and efficiency were measured, the shaft power of the expander can be calculated, which are 2.06, 2.45, 3.24, and $3.47 \mathrm{~kW}$ for the four test cases, respectively.

\subsection{Performance Analysis of Waste Heat Recovery System}

Several parameters are used to evaluate the performance of the experimental system in recovering waste heat. 


\subsubsection{Net Power Rise Rate $\varphi$}

One metric to evaluate the recovery capacity of the test system is $\varphi$, which is defined as the rise ratio of the power:

$$
\begin{gathered}
\varphi=\frac{W_{\text {net }}}{W_{g}} \\
W_{\text {net }}=W_{e}-W_{p}-W_{\text {loss }}=W_{a}-W_{\text {loss }}
\end{gathered}
$$

where $W_{g}$ is the gasoline engine power. $W_{e}$ is the expander output power. $W_{a}$ is the shaft power of the expander calculated according to the generator efficiency and electrical power, and $W_{p}$ is the plunger pump consumption power. As the pump is driven by the expander, the shaft power $W_{a}$ is equal to expander power $W_{e}$ minus pump power $W_{p} . W_{\text {loss }}$ is the gasoline engine power loss owing to pressure loss resulting from the recuperator located in the exhaust system. As shown in Figure 6, when the gasoline engine is operating at $4000 \mathrm{r} / \mathrm{min}$ and $56 \mathrm{~kW}$, the energy recovered from the exhaust increases the total power of the system by $2.74 \mathrm{~kW}$, which is equivalent to $4.9 \%$ of the engine power.

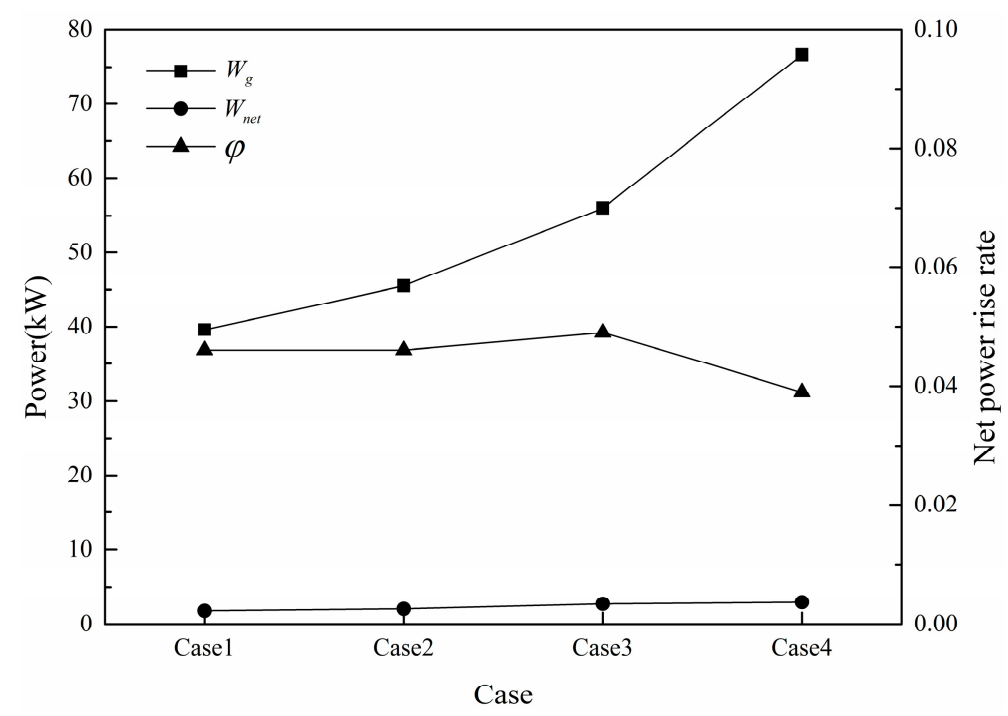

Figure 6. Net power rise rate.

\subsubsection{Thermal Efficiency of Rankine Cycle $\eta_{R}$}

The thermal efficiency of the Rankine cycle, $\eta_{R}$, is defined to evaluate the cycle's capacity to convert heat into work:

$$
\eta_{R}=\frac{W_{T i}}{\dot{Q}_{w}}=\frac{\dot{m}_{i w} \cdot\left(h_{w f t 1}-h_{w f t 2}\right)}{\dot{m}_{w} \cdot\left(h_{w f t 1}-h_{w f t 4}\right)}
$$

where $W_{T i}$ is the ideal indicated power of the expander, and $\dot{m}_{i w}$ is the theoretical mass flow rate of the working fluid, which is calculated using a thermodynamic model of the piston expander [39]. $\dot{m}_{w}$ is the mass flow rate of the working fluid, which is measured in the experiment. $h_{w f t 1}$ and $h_{w f t 2}$ are, respectively, the specific enthalpy of the working fluid at the inlet and outlet of the expander. $h_{w f t 4}$ is the specific enthalpy of the working fluid at the inlet of the recuperator. $\dot{Q}_{w}$ is the energy absorbed by the working fluid from the exhaust gas.

As shown in Figure 7, the thermal efficiency of the Rankine cycle system increases from $19.45 \%$ to $32.33 \%$ along with an increase in the power of the engine. 


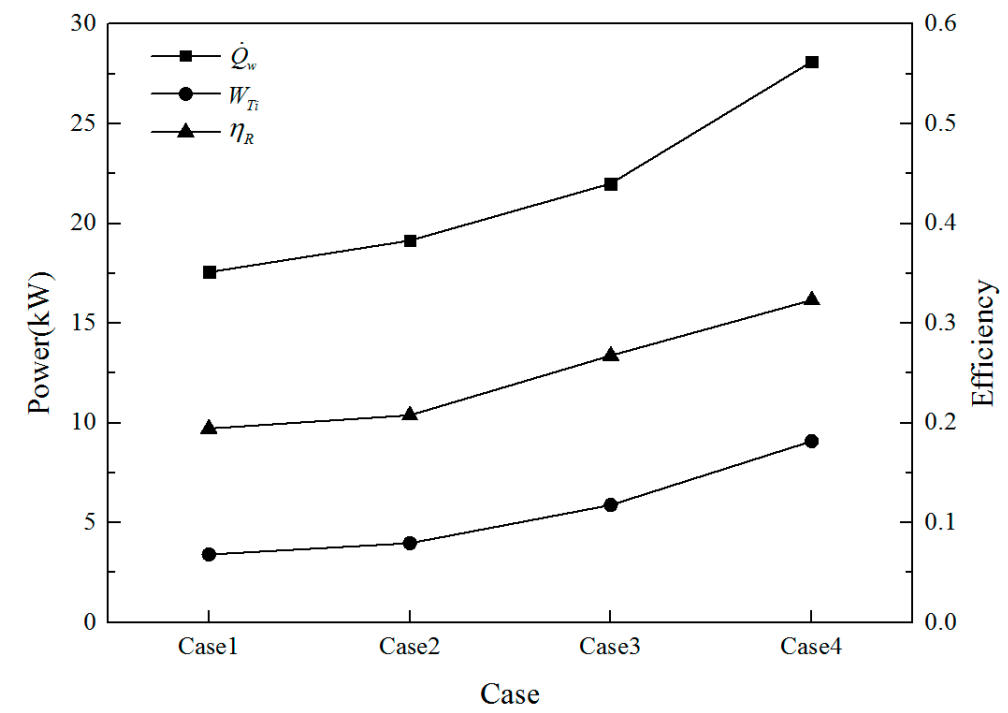

Figure 7. Thermal efficiency of the Rankine cycle.

3.3.3. Overall Combined Cycle System Efficiency $\eta_{w}$

$$
\eta_{w}=\frac{W_{e}+W_{g}}{W_{f u e l}}
$$

where $W_{\text {fuel }}$ is the fuel heat. As shown in Figure 8, when the gasoline engine power is $45.5 \mathrm{~kW}$, the original efficiency of the engine is $23.2 \%$. However, when the exhaust energy was extracted by the expander, the overall combined cycle system efficiency reached $24.4 \%$. Approximately $1.2 \%$ of the total fuel energy was recovered. For an additional weight of $50 \mathrm{~kg}$, the propulsive power increase is of about $0.7 \%$ at 3500 RPM and reaches $1.25 \%$ at 1000 RPM [40]. In this recovery system, the weight of the equipment is below $50 \mathrm{~kg}$, and the gasoline engine speed is in $4000 \mathrm{RPM}$ or above. The increase of propulsive power will be less than $0.7 \%$. Thus, the fuel economy efficiency increased by nearly $1 \%$.

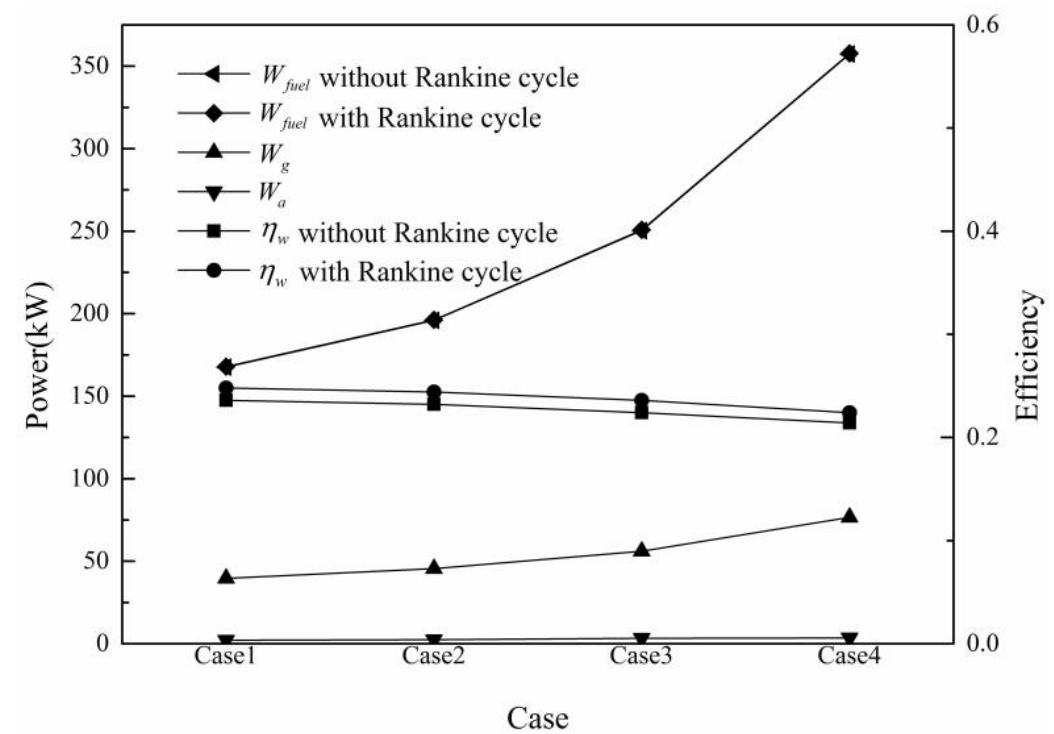

Figure 8. Overall combined cycle system efficiency. 


\section{Analysis of Potential Power Increase of the Expander}

The expander recovery system used in the above theoretical and experimental research is shown in Figure 9. When the piston moves toward the top dead point, the push rod drives the ball valve open. With the inlet valve open, high-pressure steam enters and fills the cylinder. When the piston reaches the top dead point, the inlet valve is fully open. Then, the piston performs a down stroke as the inlet valve remains open, allowing steam to fill the cylinder until the inlet valve closes.

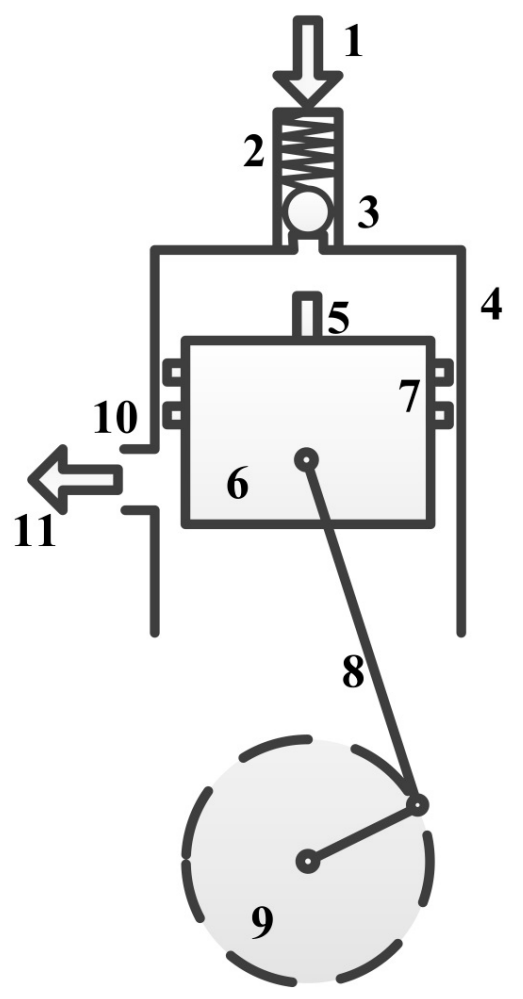

Figure 9. Structure of single-valve piston expander (1) intake; (2) spring; (3) ball valve; (4) cylinder; (5) push rod; (6) piston; (7) piston ring; (8) connecting rod; (9) crankshaft; (10) exhaust port; and (11) exhaust.

With the inlet valve closed, expansion follows, pushing the piston away from the cylinder head. The linear thrust acting on the piston end of the connecting rod is transmitted to the crankshaft, providing rotary movement. When the piston nears the bottom dead point, the exhaust port opens, and the steam in the cylinder discharges from the exhaust port. Then, the piston moves up to compress the remaining steam until the intake valve opens again to perform the next cycle.

In the expander, the intake valve opens at $40^{\circ}$ before TDC (Top dead centre) and closes at $40^{\circ}$ after TDC, as shown in Figure 10. This implies that the intake valve opens, and high-pressure steam fills the cylinder relatively early during the piston's upstroke, leading to a relatively large negative power. If the intake valve opens later, the power of the expander will be increased for the same intake valve lift-and-open period. In order to analyse the influence of the open timing of the intake valve on the expander performance, several analyses were conducted.

The offset angle is defined as the change in the angle at which the intake valve opens from its initial open angle. In this study, the initial intake phase occurs during the $320^{\circ}-40^{\circ}$ TDC period, and the exhaust phase is in the $100^{\circ}-260^{\circ}$ BDC (Bottom dead centre) period, as shown in Figure 10 . If the intake valve opens later than the original open point, the offset angle is considered positive. If it opens earlier, the offset angle is negative. When the intake valve opens too early, the cylinder may 
reach maximum pressure before TDC; this will result in negative compression work, reducing the output power and efficiency of the expander.

In this section, a thermodynamic model of the piston expander, built using MATLAB/Simulink (R2014a, MathWorks, Natick, MA, USA, 2014), is described [41]. This model consists of energy conservation, mass conservation, and heat transfer equations. The state parameters of the working fluid in the system are calculated by a function called REFPROP (v9.0, National Institute of Standards and Technology, Gaithersburg, MD, USA), which is part of NIST (National Institute of Standards and Technology) software. It is used to analyse the influence of the intake phase on expander performance.

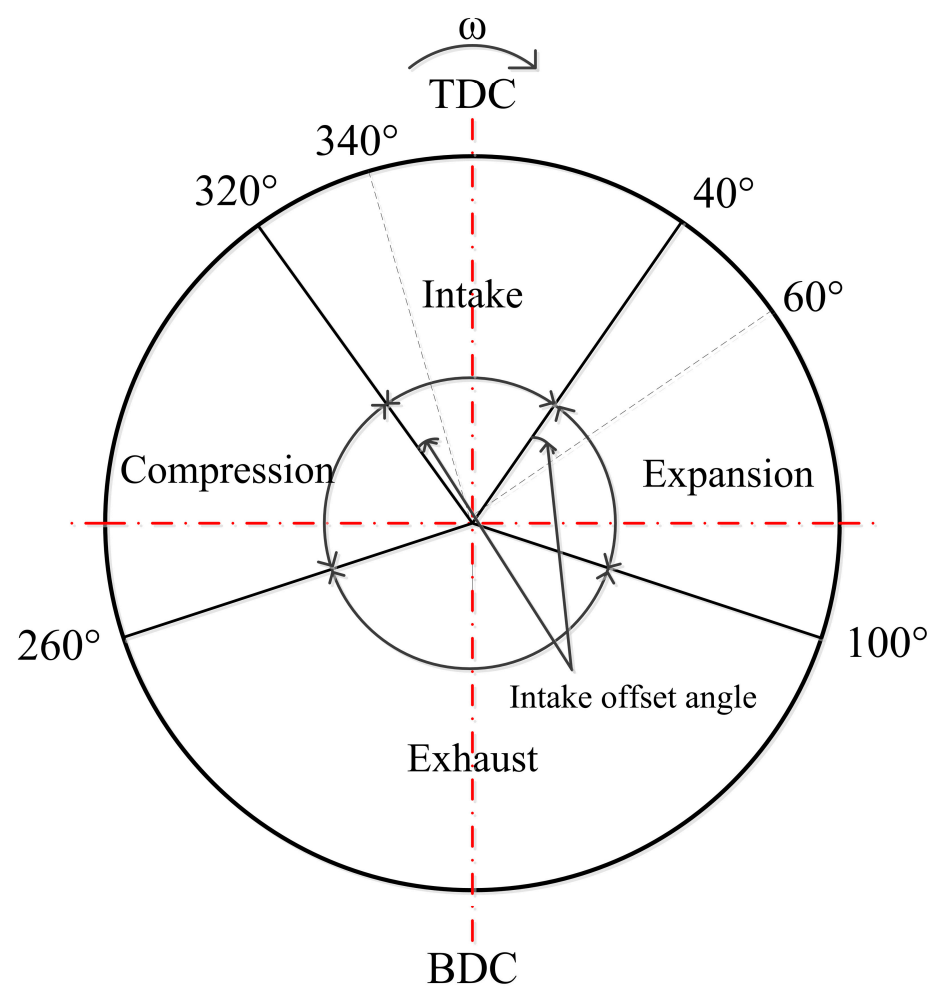

Figure 10. Valve timing diagram of the expander.

By maintaining the exhaust structure and running state of the expander, the influence of the intake angle on cylinder pressure and the instantaneous flow rate of the working fluid are determined, as shown in Figures 11 and 12. When the intake offset angle increases negatively, the maximum pressure in the cylinder increases significantly, and the maximum pressure point occurs before TDC. When the maximum pressure is attained, the cylinder pressure is greater than the intake pipe pressure. Thus, the working fluid (steam) flows backward into the intake pipe, and the working fluid mass in the cylinder is reduced. When the intake angle has a positive offset, the intake process occurs during the piston's down stroke. During that time, the volume of the cylinder gradually increases. Thus, the cylinder pressure and intake resistance decrease, which causes a decrease in the mass of the working fluid in the cylinder.

Figure 13 shows how the expander performance varies with the opening timing of the intake valve. When the intake angle offset changes from negative to positive, the rate of filling of the working fluid into the cylinder increases gradually. The output power of the expander initially increases and then decreases slightly. The output power reaches its maximum at a $20^{\circ}$ offset angle when the intake phase is in the $340^{\circ}-60^{\circ} \mathrm{TDC}$ region. A $1 \mathrm{~kW}$ increment in power can be obtained only by varying the opening timing of the intake. The isentropic efficiency of the expander initially increases and then decreases, but this variation is relatively small. The maximum efficiency occurs at a $10^{\circ}$ offset angle. 


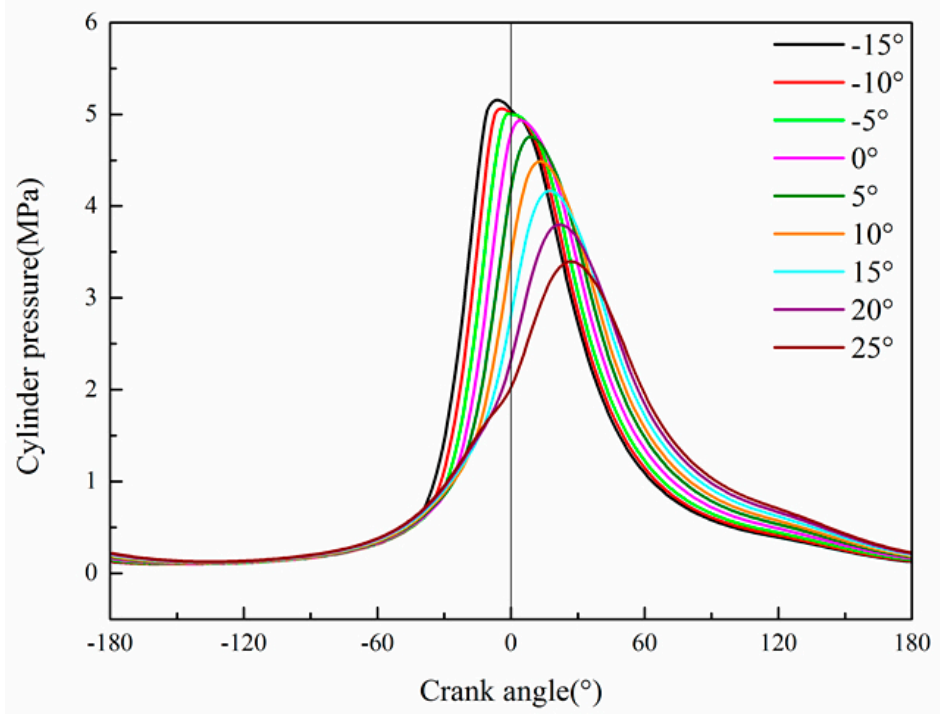

Figure 11. Influence of cylinder pressure with changes in the intake offset angle.

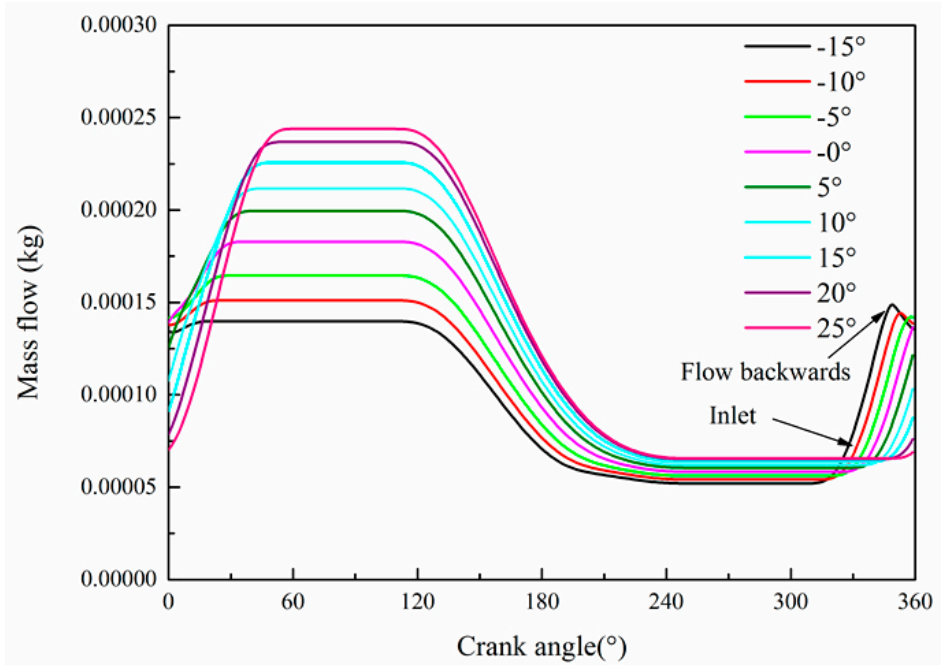

Figure 12. Influence of cylinder mass flow with changes in the intake offset angle.

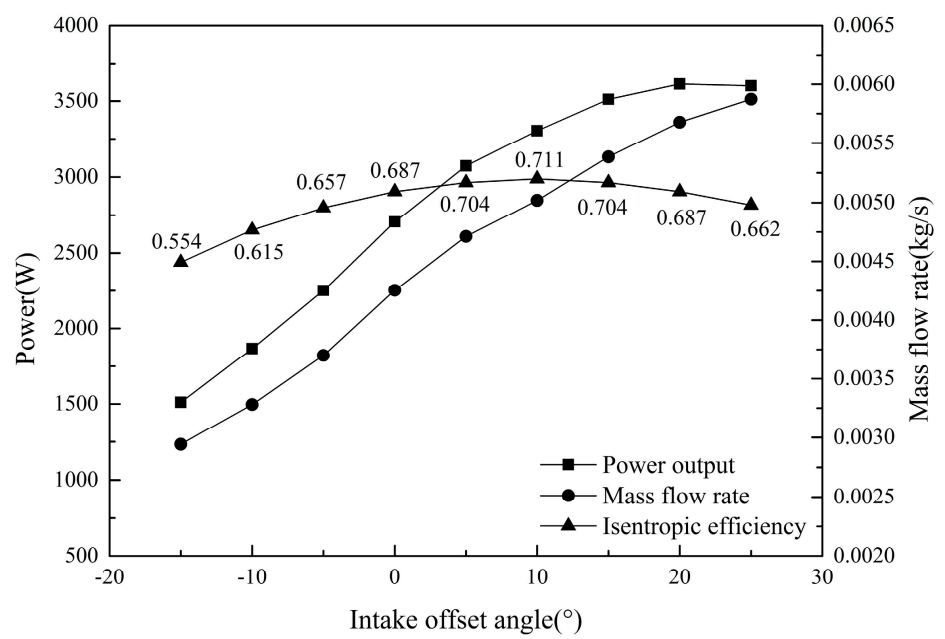

Figure 13. Effects of intake offset angle on the expander performance. 
One reason why the power output initially improves is that the intake valve opens late, but if it opens before TDC it can decrease the compression power. The other reason is that with a positive offset of the intake angle the intake process takes place mostly during the piston's down stroke, and the cylinder volume gradually increases. This causes the cylinder pressure and intake resistance to decrease and causes the mass of the working fluid in the cylinder to increase. In addition, along with the decrease in negative work, the output power and isentropic efficiency increase.

However, if the intake opening angle is too close to TDC, the intake closing time will result in incomplete expansion of the working fluid, which will decrease the output power and isentropic efficiency of the expander. Thus, the choice of intake offset angle should consider the effects on output power and isentropic efficiency.

The expander isentropic efficiency $\eta_{o i}$ is defined as the ratio of the indicated work to the ideal indicated work of the expander.

$$
\eta_{o i}=\frac{W_{i}}{W_{T i}}
$$

In this equation, $W_{i}$ is the actual indicated power of the expander. It is determined using the indicator diagram.

\section{Conclusions}

This paper presents an experimental study and analysis of the potential of a single-valve piston expander. Experimental results show that the power of the expander increases with gasoline engine speed and increase in load. The maximum net power of the expander reaches $2.74 \mathrm{~kW}$ under four test conditions. The total power of the engine and expander is increased by approximately $4.9 \%$.

A simulation of the expander intake phase shows that the output power of the expander can be improved by optimizing the intake timing. Simulation results show that the power of the expander can increase to a maximum of $1 \mathrm{~kW}$ when the intake opening timing is at a $20^{\circ}$ forward offset. Therefore, in developing the expander, selecting the intake valve opening timing is crucially important. In addition, the waste heat recovery system slightly increases the back pressure of the engine. Therefore, this Rankine cycle system shows good potential for use in recovering engine waste heat and has a bright future in engineering applications.

Acknowledgments: The authors would like to acknowledge the financial support provided by the National Basic Research Program of China (973 Program (gs1)) (Grant No. 2011CB707206).

Author Contributions: Wenzhi Gao, Wangbo He, Guanghua Li, and Ziqi Liu conceived and designed the experiments; Wenzhi Gao, Wangbo He, Guanghua Li, and Ziqi Liu performed the experiments; Wangbo He, Guanghua Li, and Ziqi Liu analysed the data; Wenzhi Gao contributed reagents/materials/analysis tools; Wenzhi Gao, Wangbo He, and Lifeng Wei wrote the paper.

Conflicts of Interest: The authors declare no conflict of interest.

\section{Abbreviation}

$\begin{array}{ll}\text { ICE } & \text { Internal combustion engine } \\ \mathrm{NA} & \text { Naturally aspirated } \\ P & \text { Pressure, Pa } \\ V & \text { Volume of the steam in the cylinder, } \mathrm{m}^{3} \\ \mathrm{~T} & \text { Temperature, }{ }^{\circ} \mathrm{C} \\ \mathrm{ET} & \text { Exhaust temperature, }{ }^{\circ} \mathrm{C} \\ \mathrm{EP} & \text { Exhaust pressure, } \mathrm{Pa} \\ \mathrm{WFT} & \text { Working fluid temperature, }{ }^{\circ} \mathrm{C} \\ \text { WFP } & \text { Working fluid pressure, Pa } \\ \varphi & \text { Net power rise rate } \\ W_{\text {net }} & \text { Net power output of recovery system, } \mathrm{W}\end{array}$




$\begin{array}{ll}W_{e} & \text { Expander power output, W } \\ W_{p} & \text { Pump power consumption, W } \\ W_{l o s s} & \text { Gasoline engine power losses, W } \\ W_{a} & \text { Shaft power of expander, W } \\ W_{g} & \text { Gasoline engine power output, W } \\ \eta_{R} & \text { Thermal efficiency of Rankine cycle system } \\ W_{T i} & \text { Ideal indicated power, W } \\ \dot{Q}_{w} & \text { Energy absorbed by the working fluid in unit time, W } \\ \dot{m}_{i w} & \text { Theoretical mass flow rate of working fluid, kg } \\ \dot{m}_{w} & \text { Mass flow rate of the working fluid, kg } \\ h_{w f t} & \text { Specific enthalpy of the working fluid, } \mathrm{kJ} / \mathrm{kg} \\ W_{i} & \text { Indicated power, W } \\ \eta_{w} & \text { Overall combined cycle system efficiency } \\ W_{f u e l} & \text { Fuel heat, W } \\ \text { NIST } & \text { National Institute of Standards and Technology } \\ \text { TDC } & \text { Top dead centre } \\ \text { BDC } & \text { Bottom dead centre } \\ W_{i} & \text { Indicated power, W } \\ \eta_{o i} & \text { isentropic efficiency of expander }\end{array}$

\section{References}

1. Katsanos, C.O.; Hountalas, D.T.; Pariotis, E.G. Thermodynamics analysis of a Rankine cycle applied on a diesel truck engine using steam and organic medium. Energy Convers. Manag. 2012, 60, 68-76. [CrossRef]

2. Wang, T.; Zhang, Y.; Peng, Z.; Shu, G. A review of researches on thermal exhaust heat recovery with Rankine cycle. Renew. Sustain. Energy Rev. 2011, 15, 2862-2871. [CrossRef]

3. Domingues, A.; Santos, H.; Costa, M. Analysis of vehicle exhaust waste heat recovery potenti al using a Rankine cycle. Energy 2013, 49, 71-85. [CrossRef]

4. Bari, S.; Hossain, S.N. Waste heat recovery from a diesel engine using shell and tube heat exchanger. Appl. Therm. Eng. 2013, 61, 355-363. [CrossRef]

5. Yang, K.; Zhang, H.; Song, S.; Zhang, J.; Wu, Y.; Zhang, Y.; Wang, H.; Chang, Y.; Bei, C. Performance Analysis of the Vehicle Diesel Engine-ORC Combined System Based on a Screw Expander. Energies 2014, 7, 3400-3419. [CrossRef]

6. He, M.; Zhang, X.; Zeng, K.; Gao, K. A combined thermodynamic cycle used for waste heat recovery of internal combustion engine. Energy 2011, 36, 6821-6829. [CrossRef]

7. Galindo, J.; Dolz, V.; Royo-Pascual, L.; Haller, R.; Melis, J. Modeling and Experimental Validation of a Volumetric Expander Suitable for Waste Heat Recovery from an Automotive Internal Combustion Engine Using an Organic Rankine Cycle with Ethanol. Energies 2016, 9, 1-18. [CrossRef]

8. Yun, K.T.; Cho, H.; Luck, R.; Mago, P.J. Modeling of reciprocating internal combustion engines for power generation and heat recovery. Appl. Energy 2013, 102, 327-335. [CrossRef]

9. Dolz, V.; Vovella, R.; Garcia, A.; Sanchez, J. HD diesel engine equipped with a bottoming Rankine cycle as a waste heat recovery system. Part 1: Study and analysis of the waste heat energy. Appl. Therm. Eng. 2012, 36, 269-278. [CrossRef]

10. Serrano, J.P.; Dolz, V.; Vovella, R.; Garcia, A. HD diesel engine equipped with a bottoming Rankine cycle as a waste heat recovery system. Part 2: Evaluation of alternative solutions. Appl. Therm. Eng. 2012, 36, $279-287$. [CrossRef]

11. Song, J.; Gu, C.W. Parametric analysis of a dual loop Organic Rankine Cycle (ORC) system for engine waste heat recovery. Energy Convers. Manag. 2015, 105, 995-1005. [CrossRef]

12. Chowdhury, J.I.; Bao, K.N.; Thornhill, D. Modelling of Evaporator in Waste Heat Recovery System using Finite Volume Method and Fuzzy Technique. Energies 2015, 8, 14078-14097. [CrossRef]

13. Morgan, D.; Patel, P.; Doyle, E.; Raymond, R.; Sakhuja, R.; Barber, K. Laboratory Test Results Low Emission Rankine-Cycle Engine with Organic-Based Working Fluid and Reciprocating Expander for Automobiles. In Proceedings of the 8th Intersociety Energy Conversion Engineering Conference, Philadelphia, PA, USA, 13-17 August 1973. 
14. Iii, C.S.; Depcik, C. Review of organic Rankine cycles for internal combustion engine exhaust waste heat recovery. Appl. Therm. Eng. 2013, 51, 711-722.

15. Wei, M.S.; Fang, J.L.; Ma, C.C.; Danish Syed, N. Waste heat recovery from heavy-duty dieselengine exhaust gases by medium temperature ORC system. Sci. China Technol. Sci. 2011, 54, 2746-2753. [CrossRef]

16. Xie, H.; Yang, C. Dynamic behavior of Rankine cycle system for waste heat recovery of heavy duty diesel engines under driving cycle. Appl. Energy 2013, 112, 130-141. [CrossRef]

17. Wang, J.F.; Yan, Z.Q.; Zhao, P.; Dai, Y.P. Off-design performance analysis of a solar powered organic Rankine cycle. Energy Convers. Manag. 2014, 80, 150-157. [CrossRef]

18. Hajabdollahi, Z.; Hajabdollahi, F.; Tehrani, M.; Hajabdollahi, H. Thermo-economic environmental optimization of Organic Rankine Cycle for diesel waste heat recovery. Energy 2013, 63, 142-151. [CrossRef]

19. Latz, G.; Erlandsson, O.; Skåre, T.; Contet, A.; Andersson, S.; Munch, K. Performance Analysis of a Reciprocating Piston Expander and a Plate Type Exhaust Gas Recirculation Boiler in a Water-Based Rankine Cycle for Heat Recovery from a Heavy Duty Diesel Engine. Energies 2016, 9, 495. [CrossRef]

20. Zhang, Y.Q.; Wu, Y.T.; Xia, G.D.; Ma, C.F.; Ji, W.N.; Liu, S.W.; Yang, K.; Yang, F.B. Development and experimental study on organic Rankine cycle system with single-screw expander for waste heat recovery from exhaust of diesel engine. Energy 2014, 77, 499-508. [CrossRef]

21. Qiu, G.; Liu, H.; Riffat, S. Expanders for micro-CHP systems with organic Rankine cycle. Appl. Therm. Eng. 2011, 31, 3301-3307. [CrossRef]

22. Aoun, B. Micro Combined Heat and Power Operating on Renewable Energy for Residential Building; HAL-SHS: Paris, France, 2008.

23. Kolasiński, P.; Błasiak, P.; Rak, J. Experimental and Numerical Analyses on the Rotary Vane Expander Operating Conditions in a Micro Organic Rankine Cycle System. Energies 2016, 9, 606. [CrossRef]

24. Gntutek, Z.; Kolasiński, P. The Application of Rotary Vane Expanders in Organic Rankine Cycle Systems-Thermodynamic Description and Experimental Results. J. Eng. Gas Turbines Power 2013, 135. [CrossRef]

25. Peterson, R.B.; Wang, H.; Herron, T. Performance of small-scale regenerative Rankine power cycle employing a scroll expander, Proceedings of the Institution of Mechanical Engineers Part A. J. Power Energy 2008, 222, 271-282. [CrossRef]

26. Wang, H.; Peterson, R.B.; Herron, T. Experimental performance of a compliant scroll expander for an organic Rankine cycle, Proceedings of the Institution of Mechanical Engineers Part A. J. Power Energy 2009, 223, 863-872. [CrossRef]

27. Choi, M.K.; Stokley, J.R.; Morehouse, J.H. Analysis of Commercial and Residential Solar Absorption and Rankine Cooling Systems; Final Report to U.S. DOE, No. DE-AC03-81SF11573; United States Department of Energy: Washington, DC, USA, 1982.

28. Curran, H.M. Mechanical Systems and Components. In Active Solar Systems; Lof, G., Ed.; MIT Press: Cambridge, MA, USA, 1993; Chapter 19.

29. Muhammad, I.; Muhammad, U.; Park, B.S.; Lee, D.H. Volumetric expanders for low grade heat and waste heat recovery applications. Renew. Sustain. Energy Rev. 2016, 57, 1090-1109.

30. Young, M.K.; Dong, G.S.; Chang, G.K. Optimization of Design Pressure Ratio of Positive Displacement Expander for Vehicle Engine Waste Heat Recovery. Energies 2014, 7, 6105-6117.

31. Lemort, V.; Quoilin, S.; Cuevas, C.; Lebrun, J. Testing and modeling a scroll expander integrated into an organic Rankine cycle. Appl. Therm. Eng. 2009, 29, 3094-3102. [CrossRef]

32. Badami, M.; Mura, M. Preliminary design and controlling strategies of a small-scale wood waste Rankine cycle with a reciprocating steam engine. Energy 2009, 34, 1315-1324. [CrossRef]

33. Capata, R.; Toro, C. Feasibility analysis of a small-scale ORC energy recovery system for vehicular application. Energy Convers. Manag. 2014, 86, 1078-1090. [CrossRef]

34. Li, G.; Zhang, H.; Yang, F.; Song, S.; Chang, Y.; Yu, F.; Wang, J.; Yao, B. Preliminary Development of a Free Piston Expander-Linear Generator for Small-Scale Organic Rankine Cycle (ORC) Waste Heat Recovery System. Energies 2016, 9, 300. [CrossRef]

35. Endo, T.; Kawajiri, S.; Kojima, Y.; Takahashi, K. Study on Maximizing Exergy in Automotive Engines; SAE World Congress \& Exhibition: Detroit, MI, USA, 2007.

36. Glavatskaya, Y.; Podevin, P.; Lemort, V.; Shonda, O.; Descombes, G. Reciprocating Expander for an Exhaust Heat Recovery Rankine Cycle for a Passenger Car Application. Energies 2012, 5, 1751-1765. [CrossRef] 
37. Chiong, M.C.; Rajoo, S.; Romagnoli, A. Nozzle Steam Piston Expander for Engine Exhaust Energy Recovery. 2015. Available online: http:/ / papers.sae.org/2015-01-0126/ (accessed on 28 November 2016).

38. Ringler, J.; Seifeit, M.; Guyotot, V.; Hübner, W. Rankine cycle for waste heat recovery of IC engines. SAE Int. J. Engines 2009, 2, 67-76. [CrossRef]

39. Li, G.; Gao, W.; Bian, Q. Thermodynamic analysis and fluids screening for a gasoline engine exhaust heat recovery system. J. Renew. Sustain. Energy 2014, 6, 1829-1851. [CrossRef]

40. Battista, D.D.; Mauriello, M.; Cipollone, R. Waste heat recovery of an ORC-based power unit in a turbocharged diesel engine propelling a light duty vehicle. Appl. Energy 2015, 152, 109-120. [CrossRef]

41. Gao, W.; Zhai, J.; Li, G.; Bian, Q.; Feng, L. Performance evaluation and experiment system for waste heat recovery of diesel engine. Energy 2013, 55, 226-235.

(C) 2016 by the authors; licensee MDPI, Basel, Switzerland. This article is an open access article distributed under the terms and conditions of the Creative Commons Attribution (CC-BY) license (http://creativecommons.org/licenses/by/4.0/). 